\title{
Menopausal Hormone Therapy after Breast Cancer
}

\section{Citation}

Colditz, Graham A. 2005. Menopausal hormone therapy after breast cancer. Breast Cancer Research 7(4): 168-170.

\section{Published Version}

doi:10.1186/bcr1272

\section{Permanent link}

http://nrs.harvard.edu/urn-3:HUL.InstRepos:4595431

\section{Terms of Use}

This article was downloaded from Harvard University's DASH repository, and is made available under the terms and conditions applicable to Other Posted Material, as set forth at http:// nrs.harvard.edu/urn-3:HUL.InstRepos:dash.current.terms-of-use\#LAA

\section{Share Your Story}

The Harvard community has made this article openly available.

Please share how this access benefits you. Submit a story.

Accessibility 


\title{
Commentary \\ Menopausal hormone therapy after breast cancer
} Graham A Colditz

\author{
Professor of Medicine, Harvard Medical School, Boston, Massachusetts, USA, and Honorary Professor of Population Health, University of Queensland, \\ Brisbane, Australia
}

Corresponding author: Graham A Colditz, graham.colditz@channing.harvard.edu

Published: 1 June 2005

This article is online at http://breast-cancer-research.com/content/7/4/168

(c) 2005 BioMed Central Ltd

Breast Cancer Research 2005, 7:168-170 (DOI 10.1186/bcr1272)

See related research by Col et al., http://breast-cancer-research.com/content/7/4/R535

\begin{abstract}
The use of postmenopausal hormone therapy after breast cancer remains controversial. Evidence shows variation by study design, and even among three randomized controlled trials there is substantial heterogeneity of results. Two Swedish trials of comparable size show relative risks of recurrence of 3.3 and 0.82 on comparing women receiving postmenopausal hormone therapy with control women. The extent of use of tamoxifen and concomitant use of progestins in combination with estrogen, although raised as one possible explanation for this heterogeneity, are not supported by evidence from trials of high-dose progestins used after breast cancer. Caution is needed when considering the use of postmenopausal hormone therapy after breast cancer.
\end{abstract}

There is now resounding evidence that use of exogenous hormones by postmenopausal women increases risk for breast cancer [1-3]. Likewise, obesity among postmenopausal women with breast cancer is a major determinant of relapse and mortality $[4,5]$, being directly related to poor outcomes. On the other hand, tamoxifen provides lasting reduction in risk for recurrence and mortality [6], an effect that is independent of adjuvant chemotherapy. Despite this evidence relating endogenous and exogenous hormones to breast cancer risk and outcomes, debate continues regarding the use of postmenopausal hormones for symptom relief among women with breast cancer. Col and colleagues [7], in this issue of Breast Cancer Research, report a systematic review in which they identified eight observational studies and two randomized controlled trials of postmenopausal hormone therapy. They note that the combined results for the two trials show increased risk for recurrence (relative risk $[R R]=3.4$, $95 \%$ confidence interval $[\mathrm{Cl}]=1.6$ to 7.3 ), which contrasts with the findings of the observational results, which show a decrease in risk $(\mathrm{RR}=0.6,95 \% \mathrm{Cl}=0.5-0.8)$. While noting heterogeneity between the results according to study design, $\mathrm{Col}$ and colleagues do not explore the data to describe the possible sources of heterogeneity $[8,9]$ beyond study design.
As noted below, the quality of data reporting limits their ability in this regard.

Biologic evidence supports estrogenic exposures being related to incidence and poor outcome among women with breast cancer. Weight after diagnosis is a strong predictor of outcome [4], and weight gain after diagnosis is associated with increased recurrence and mortality [5]. There are direct positive relations between adiposity and circulating estrogens [10], and between adult weight gain and postmenopausal breast cancer risk [11], and circulating endogenous hormones represent the primary explanation for this positive relation between adiposity and postmenopausal breast cancer incidence [12]. Together, these data support an increase in incidence of breast cancer with use of postmenopausal hormone therapy. Should the effect of exogenous postmenopausal hormonal therapy differ after diagnosis, when adiposity and weight gain have adverse effects on recurrence and mortality?

To cloud further the current evidence, a third randomized trial [13], which has been published since the synthesis by Col and colleagues, found no increase in risk with use of postmenopausal hormone therapy $(\mathrm{RR}=0.8,95 \% \mathrm{Cl}=0.4-1.9)$, based on 4.1 years of follow up in 434 women (Table 1). The authors raise the intriguing possibility that the choice of hormone regimen may modify the risk for recurrence and account for some of the heterogeneity observed. This trial is of comparable size and design to the HABITS (Hormone Replacement Therapy after Breast Cancer - Is It Safe?) trial, also conducted in Sweden [14]. Clearly, more detailed analysis of this small body of evidence might improve our understanding of the difference between unopposed estrogen and combination estrogen plus progestin therapy among women who have been treated for histologically confirmed breast cancer. Alternatively, we can consider other 
Table 1

Randomized controlled trials of combination estrogen plus progestin postmenopausal hormone therapy and recurrence of breast cancer

\begin{tabular}{lcccccc}
\hline & Year & $\begin{array}{c}\text { Number of } \\
\text { patients } \\
\text { randomized }\end{array}$ & $\begin{array}{c}\text { Number of } \\
\text { patients with } \\
\text { follow up }\end{array}$ & $\begin{array}{c}\text { Duration of } \\
\text { follow up }\end{array}$ & $\begin{array}{c}\text { Number of } \\
\text { recurrences (hormone } \\
\text { therapy/control) }\end{array}$ & RR (95\% Cl) \\
\hline Muthor [ref.] & 2000 & 100 & 83 & 6 months & $2 / 1$ & 2 \\
Holmberg and Anderson [15] & 2004 & 434 & 345 & 2.1 years & $26 / 7$ & $3.3(1.5-7.4)$ \\
von Schoultz and Rutqvist [14] & 2005 & 378 & 359 & 4.1 years & $11 / 13$ & $0.82(0.35-1.9)$ \\
\hline
\end{tabular}

$\mathrm{Cl}$, confidence interval; $\mathrm{RR}$, relative risk.

evidence on use of progestins after diagnosis and breast cancer outcomes.

Several recent studies suggested that, when drug therapies are considered, observational studies give measures of effect comparable to those observed through randomized trials $[15,16]$. However, here we have significant heterogeneity of results both within the randomized trials (Stockholm trial [13] and HABITS trial [14], both conducted in Sweden) and between the observational and randomized study findings in the systematic review conducted by $\mathrm{Col}$ and coworkers [7]. As Col and colleagues note, the observational studies often did not report results separately for women using combination hormone therapy and those using unopposed estrogens. It is noteworthy that the Stockholm trial attempted to minimize the use of progestogen, and the HABITS trial recommended either cyclical estrogen plus progestin for women with uterine bleeding within 2 years of randomization or continuous combined therapy for other women with a uterus. The Stockholm trial recommended $20 \mathrm{mg}$ medroxyprogesterone acetate (MPA) for 14 days every 105 days for women over 55 years of age. The Stockholm trial also included a higher percentage of patients receiving concomitant adjuvant tamoxifen therapy than did the HABITS trial $(52 \%$ versus $21 \%)$, and a lower percentage of patients with node-positive breast cancer (16\% versus $26 \%$ ). Thus, a lower risk population may have been studied in the Stockholm trial, with lower exposure to MPA.

It has been hypothesized that MPA might act through glucocorticoid receptors to reduce metastatic potential [17]. Two trials that used high-dose MPA for 6 months in women with breast cancer and followed them for more than a decade $[18,19]$ fail to support a reduction in recurrence. A systematic review of trials of MPA in combination with either tamoxifen or combination chemotherapy after breast cancer sheds some light on this possibility. Synthesis of data from randomized trials published through 1996 shows no overall improvement in median survival among women treated with MPA, and no survival advantage for higher versus lower doses of endocrine therapy (including MPA) [20]. Finally, given that estrogen plus progestin clearly increases the incidence of breast cancer, and that the Women's Health Initiative showed that the distribution of tumor stage was comparable in the estrogen plus progestin arm and the placebo arm [21], treatment with MPA before diagnosis does not appear to reduce metastatic potential. These data combined then do not provide strong evidence that merely the dose or frequency of MPA administration could account for the heterogeneity among the Swedish trials. Furthermore, these data clearly do not support MPA as an agent to reduce recurrence and improve survival.

To conclude, given the divergent results from the randomized trials, we recommend caution. Symptom management remains a challenge in some postmenopausal women. The consensus statement suggesting that other established means of controlling symptoms or preventing osteoporosis should be utilized before considering estrogen and progestin therapy in these women remains prudent [22].

\section{Competing Interests}

The author(s) declare that they have no competing interests.

\section{References}

1. Colditz GA, Hankinson SE, Hunter DJ, Willett WC, Manson JE, Stampfer MJ, Hennekens C, Rosner B, Speizer FE: The use of estrogens and progestins and the risk of breast cancer in postmenopausal women. N Engl J Med 1995, 332:1589-1593.

2. Beral V: Breast cancer and hormone-replacement therapy in the Million Women Study. Lancet 2003, 362:419-427.

3. Rossouw JE, Anderson GL, Prentice RL, LaCroix AZ, Kooperberg C, Stefanick ML, Jackson RD, Beresford SA, Howard BV, Johnson $\mathrm{KC}$, et al:: Risks and benefits of estrogen plus progestin in healthy postmenopausal women: principal results From the Women's Health Initiative randomized controlled trial. JAMA 2002, 288:321-333

4. Coates RJ, Clark WS, Eley JW, Greenberg RS, Huguley CM Jr, Brown RL: Race, nutritional status, and survival from breast cancer. J Natl Cancer Inst 1990, 82:1684-1692.

5. Kroenke $\mathrm{CH}$, Chen WY, Rosner B, Holmes MD: Weight, weight gain, and survival after breast cancer diagnosis. J Clin Oncol 2005, 23:1370-1378.

6. Early Breast Cancer Trialists' Collaborative Group: Effects of chemotherapy and hormonal therapy for early breast cancer on recurrence and 15-year survival: an overview of the randomised evidence. Lancet 2005, 365:1687-1717.

7. Col NF, Kim JA, Chlebowski RT: Menopausal hormone therapy after breast cancer: a meta-analysis and critical appraisal of the evidence. Breast Cancer Res 2005, 7:R535-R540.

8. Berlin JA: The benefits of heterogeneity in meta-analysis of data from epidemiologic studies. Invited commentary. Am J Epidemiol 1995, 142:383-387. 
9. Colditz G, Burdick E, Mosteller F: Heterogeneity in meta-analysis of data from epidemiologic studies: a commentary. $A m \mathrm{~J}$ Epidemiol 1995, 142:371-382.

10. Hankinson SE, Willett WC, Manson JE, Hunter DJ, Colditz GA, Stampfer MJ, Longcope C, Speizer FE: Alcohol, height, and adiposity in relation to estrogen and prolactin levels in postmenopausal women. J Natl Cancer Inst 1995, 87:1 297-1302.

11. Huang Z, Hankinson SE, Colditz GA, Stampfer MJ, Hunter DJ, Manson JE, Hennekens $\mathrm{CH}$, Rosner B, Speizer FE, Willett WC: Dual effects of weight and weight gain on breast cancer risk. JAMA 1997, 278:1407-1411.

12. Key TJ, Appleby PN, Reeves GK, Roddam A, Dorgan JF, Longcope C, Stanczyk FZ, Stephenson HE Jr, Falk RT, Miller R, et al.: Body mass index, serum sex hormones, and breast cancer risk in postmenopausal women. J Natl Cancer Inst 2003, 95: 1218-1226.

13. von Schoultz E, Rutqvist LE: Menopausal hormone therapy after breast cancer: the Stockholm randomized trial. J Natl Cancer Inst 2005, 97:533-535.

14. Holmberg L, Anderson H: HABITS (hormonal replacement therapy after breast cancer - is it safe?), a randomised comparison: trial stopped. Lancet 2004, 363:453-455

15. Benson K, Hartz AJ: A comparison of observational studies and randomized, controlled trials. $N$ Engl J Med 2000, 342: 1878-1886.

16. Concato J, Shah N, Horwitz Rl: Randomized, controlled trials, observational studies, and the hierarchy of research designs. N Engl J Med 2000, 342:1887-1892.

17. Palmieri D, Halverson DO, Ouatas $T$, Horak CE, Salerno M, Johnson J, Figg WD, Hollingshead M, Hursting S, Berrigan D, et al.: Medroxyprogesterone acetate elevation of Nm23-H1 metastasis suppressor expression in hormone receptor-negative breast cancer. J Nat/ Cancer Inst 2005, 97:632-642.

18. Focan C, Beauduin M, Salamon E, de Greve J, de Wasch G, Lobelle JP, Majois F, Tagnon A, Tytgat J, van Belle S, et al:: Adjuvant high-dose medroxyprogesterone acetate for early breast cancer: 13 years update in a multicentre randomized trial. $\mathrm{Br} \mathrm{J}$ Cancer 2001, 85:1-8.

19. Hupperets PS, Wils JA Volovics L Schouten $\sqcup$, Fickers MM, Bron HN, Jager JJ, de Jong JM, Blijham GH: Adjuvant chemohormonal therapy with cyclophosphamide, doxorubicin and 5fluorouracil (CAF) with or without medroxyprogesterone acetate (MPA) for node-positive cancer patients, update at 12 years follow up. Breast 2001, 10:35-37.

20. Stockler M, Wilcken NR, Ghersi D, Simes RJ: Systematic reviews of chemotherapy and endocrine therapy in metastatic breast cancer. Cancer Treat Rev 2000, 26:151-168.

21. Chlebowski RT, Hendrix SL, Langer RD, Stefanick ML, Gass M, Lane D, Rodabough RJ, Gilligan MA, Cyr MG, Thomson CA, et al.: Influence of estrogen plus progestin on breast cancer and mammography in healthy postmenopausal women: the Women's Health Initiative Randomized Trial. JAMA 2003, 289: 3243-3253.

22. Anonymous: Treatment of estrogen deficiency symptoms in women surviving breast cancer. The Hormone Foundation, Canadian Breast Cancer Research Initiative, National Cancer Institute of Canada, Endocrine Society, and the University of Virginia Cancer Center and Woman's Place. J Clin Endocrinol Metab 1998, 83:1993-2000.

23. Marsden J, Whitehead M, Hern RA, Baum M, Sacks N: Are randomized trials of hormone replacement therapy in symptomatic women with breast cancer feasible? Fertil Steril 2000, 73:292-199. 